\title{
How a Root-Microbial System Regulates the Response of Soil Respiration to Temperature and Moisture in a Plantation
}

\author{
Wenchen Song', Xiaojuan Tong'* Jinsong Zhang²*, Ping Meng², Jun Li \\ ${ }^{1}$ College of Forestry, Beijing Forestry University, Beijing, China \\ ${ }^{2}$ Key Laboratory of Tree Breeding and Cultivation of State Forestry Administration, Research Institute of Forestry, \\ Chinese Academy of Forestry, Beijing, China \\ ${ }^{3}$ Key Laboratory of Water Cycle and Related Land Surface Processes, Institute of Geographic Sciences \\ and Natural Resources Research, Chinese Academy of Sciences, Beijing, China
}

Received: 31 August 2017

Accepted: 17 December 2017

\begin{abstract}
Understanding the response of soil respiration to changes in temperature and moisture is critical to accurately assess the impact of afforestation on regional carbon balance. In order to investigate the response of soil respiration to soil temperature and moisture, we partitioned soil respiration into three components (heterotrophic respiration, root respiration, and rhizomicrobial respiration) using ${ }^{13} \mathrm{C}$ natural abundance during the growing season in a Robinia pseudoacacia plantation in northern China. Root respiration and soil microbial respiration had a significantly positive relationship with soil temperature. Heterotrophic respiration was positively correlated with soil moisture, while rhizomicrobial respiration significantly decreased with a reduction in soil moisture. Our findings suggest that the responses of plant roots and soil microorganisms to soil temperature and moisture were different. According to the prediction of the rootmicrobial model developed in this study, average soil respiration will increase by $12 \mathrm{mg} \mathrm{C} \mathrm{m}^{-2} \mathrm{~h}^{-1}$ when soil temperature increases by $2^{\circ} \mathrm{C}$ in the plantation. By modelling the relationship of a root-microbial system during the growing season in a plantation in northern China, the temperature and moisture sensitivities of soil respiration can be characterized.
\end{abstract}

Keywords: soil respiration, temperature, moisture, root-microbial system, natural $\delta^{13} \mathrm{C}$ abundance

\section{Introduction}

Soil respiration is the largest source of $\mathrm{CO}_{2}$ emissions from terrestrial ecosystems [1]. It is estimated to be $98 \pm 12 \mathrm{Pg} \mathrm{C} \mathrm{yr}^{-1}$, or 10 times higher than the cumulative industrial $\mathrm{CO}_{2}$ emissions by fossil fuels [2-3]. Forests are

*e-mail: tongxj@bjfu.edu.cn, zhangjs@caf.ac.cn a major part of the terrestrial ecosystem carbon sink [4]. Plantations have functioned as a persistent carbon sink and account for about half of the total carbon sink in forest stands in China [5]. Due to the large magnitude of carbon flux and stock of the plantations, a slight change in the uptake and storage of carbon in these ecosystems could have substantial consequences for the global carbon cycle and feedback to climate change [5]. However, soil carbon fixation and the response of soil respiration to climate 
change remains uncertain [4]. Thus, it is important to understand the mechanism determining the variation in soil respiration of the plantations [6-8].

Soil respiration is divided into autotrophic root respiration and soil heterotrophic respiration. Autotrophic root respiration can be further divided into two parts: root respiration and rhizomicrobial respiration [9]. The responses of root respiration, rhizomicrobial respiration and heterotrophic respiration to environmental factors must be determined to estimate soil respiration precisely and to quantify their contribution to the global carbon cycle [9-10]. However, it is difficult to partition autotrophic root respiration into root respiration and rhizomicrobial respiration. Consequently, little attention has been paid to the soil temperature and moisture sensitivity of root respiration and rhizomicrobial respiration.

Most studies on the partitioning of autotrophic root respiration were conducted under controlled conditions [11]. Isotope methods are advantageous for in situ measurement, allowing for accurate tracing and cause almost no disturbance. Among the isotope methods available, the natural $\delta^{13} \mathrm{C}$ abundance method of microbial biomass is suitable for partitioning rhizosphere respiration in the field [9, 11-12]. Errors are possible using isotopic partitioning techniques, but these can be reduced by using Bayesian isotopic mixing models (SIAR) [13].

Soil respiration is dominantly controlled by soil temperature [14-16]. The temperature sensitivity efficiency is dependent on such environmental variables as water conditions [17], soil physical properties [18], soil nutrients [19], vegetation type [6], and priming effect [20-21]. Under field conditions, soil respiration has no significant linear relationship with soil temperature [14, 22] and soil moisture [23]. Soil moisture strongly affects the dynamics of soil organic matter (SOM) and is an important environmental variable in all models predicting the change of soil carbon stock from site to global scale[24]. However, different sources of $\mathrm{CO}_{2}$ from soil respiration may respond differently to environmental changes. It is therefore important to estimate the response of each source to climate change to estimate soil respiration more precisely [25]. So far, less attention has been placed on the mechanisms of the root-microbial system response to soil respiration and the variations of soil temperature and soil moisture. How do root-microbial systems (especially rhizomicrobial organisms) play a role in the sensitivity of soil respiration to environmental factors in the plantation? To answer this question, we investigated the response of different sources of soil respiration to soil temperature and soil moisture.

In this study, soil respiration was measured during the growing season in a Robinia pseudoacacia plantation in northern China. Soil respiration was partitioned into root respiration, rhizomicrobial respiration, and heterotrophic respiration using ${ }^{13} \mathrm{C}$ natural abundance. The main objectives of this study are: 1) to assess the relationship of different sources of soil respiration to soil temperature and moisture, and 2) to simulate the effect of soil temperature and moisture on soil respiration.

\section{Experimental}

\section{Site Description}

This study was conducted at the Xiaolangdi Research Station forest ecosystem, which is located in a semi-arid region of Henan Province, China $\left(35^{\circ} 01^{\prime} \mathrm{N}, 112^{\circ} 28^{\prime} \mathrm{E}\right.$; elevation $410 \mathrm{~m}$ ). The average annual temperature of this station is $13.4^{\circ} \mathrm{C}$. Annual sunshine hours are 2,367.7 and annual sunshine rate is $54 \%$. The Robinia pseudoacacia plot in this study was selected in the middle of a semisunny slope. Soil type is mainly brown loam and the average soil thickness is $1.2 \mathrm{~m}$. Stand density is 1,905 stems $\mathrm{ha}^{-1}$ and the canopy density is 0.9 . The average tree height is $10.4 \mathrm{~m}$ and the average diameter of breast height (DBH) is $10.5 \mathrm{~cm}$.

\section{Sampling and Analysis}

Soil respiration in the plots $(n=9)$ was measured with a Li-Cor 8100 soil $\mathrm{CO}_{2}$ Flux system (Li-Cor Inc., Lincoln, NE, USA) 4 times per month throughout the representative days in the growing season (from April to September 2014, 2 times early in the month and 2 times late in the month). Soil temperature was measured every 10 min near each collar (see next paragraph) by AV-10T (Avalon, USA), while soil moisture was measured at a 20 $\mathrm{cm}$ soil depth by $\mathrm{ECH}_{2} \mathrm{O}$ (Dielectric Aquamete, USA).

The $\delta^{13} \mathrm{C}$ values of gas fluxes were measured using the static chamber method and calculated by the Keeling plot method described by Pataki et al. [26]. Based on a linear increase of $\mathrm{CO}_{2}$ concentration in the chambers with time, soil $\mathrm{CO}_{2}$ efflux was calculated. The chambers were randomly placed in each plot and polyvinyl chloride collars were inserted to a depth of $20 \mathrm{~cm}$. The $\delta^{13} \mathrm{C}$ values of soil $\mathrm{CO}_{2}$ flux were measured according to the $\delta^{13} \mathrm{C}$ values of the gas in the chamber and calculated by Keeling plot [26]. After gas sampling was completed, soil and roots were sampled in situ with a soil auger. Roots and soil should be sampled at the same place where soil gas was sampled to make their $\delta^{13} \mathrm{C}$ values representative. For details see Song et al. [12].

The $\delta^{13} \mathrm{C}$ values of $\mathrm{CO}_{2}$, soil, and root samples were analyzed using a DELTA V Advantage isotope ratio mass spectrometer (Flash EA1112 HT Elemental Analyzer, Thermo Fisher Scientific Inc., USA). Gas samples were frozen to enrichment in a cold trap of Precon, run through the mass spectrometer to detect the ${ }^{13} \mathrm{C}$ and ${ }^{12} \mathrm{C}$ ratios of $\mathrm{CO}_{2}$, and compared with the international standard substance (atmospheric) to calculate $\delta^{13} \mathrm{C}$ values. The measurement precision for $\delta^{13} \mathrm{C}$ was $\pm<0.1 \%$.

\section{Calculating Root Respiration, Heterotrophic Respiration, and Rhizomicrobial Respiration}

The relatively high $\delta^{13} \mathrm{C}$ values result from carbon inputs to the original native land, in which corn $\left(\mathrm{C}_{4}\right)$ was planted before being converted to a $\mathrm{C}_{3}$ plantation. The contributions of autotrophic respiration (root-derived) 
$\left(f_{\mathrm{AR}}\right)$ and heterotrophic respiration (SOM-derived) $\left(f_{\mathrm{HR}}\right)$ to total soil respiration were calculated using linear two-source isotopic mixing models:

$$
\begin{gathered}
f_{A R}=\frac{\left(\delta^{13} C_{G}-\delta^{13} C_{S O M}\right)}{\left(\delta^{13} C_{R}-\delta^{13} C_{S O M}\right)} \\
f_{H R}=1-f_{A R} \\
Q_{T}=Q_{A R}+Q_{H R}
\end{gathered}
$$

...where $\delta^{13} C_{G}, \delta^{13} C_{S O M}$, and $\delta^{13} C_{R}$ are the $\delta^{13} \mathrm{C}$ values of soil $\mathrm{CO}_{2}$, heterotrophic respiration, and autotrophic respiration, respectively. Since the $\delta^{13} \mathrm{C}$ isotope signature of autotrophic respiration was the same as the $\delta^{13} \mathrm{C}$ value of roots [27] and the $\delta^{13} \mathrm{C}$ isotope signature of heterotrophic respiration corresponded to the $\delta^{13} \mathrm{C}$ value of SOM in forest ecosystems [28], the $\delta^{13} C_{R}$ and $\delta^{13} C_{S O M}$ could be replaced by the $\delta^{13} \mathrm{C}$ value of roots and rootless SOM following the principle described by Werth and Kuzyakov [11]. The values of $f_{A R}$ and $f_{H R}$ are the proportional contributions of autotrophic respiration and heterotrophic respiration to soil $\mathrm{CO}_{2} . Q_{T}, Q_{A R}$, and $Q_{H R}$ are the amount of total $\mathrm{CO}_{2}$ flux, autotrophic respiration, and heterotrophic respiration, respectively.

Following the method of Kuzyakov [29], the proportion of rhizomicrobial respiration $\left(f_{\mathrm{RMR}}\right)$ is given by:

$$
f_{\mathrm{RMR}}=\frac{\left(\delta^{13} C_{M O}-\delta^{13} C_{S O M}\right)\left(\delta^{13} C_{G}-\delta^{13} C_{R}\right)}{\left(\delta^{13} C_{R}-\delta^{13} C_{S O M}\right)\left(\delta^{13} C_{M O}-\delta^{13} C_{R}\right)}
$$

...where $\delta^{13} C_{M O}$ is the $\delta^{13} \mathrm{C}$ value of SOM of the plantation. Isotopic fractionations should be considered to avoid large error [11]. The isotopic fractionation between SOM and $\mathrm{SOM}$-derived $\mathrm{CO}_{2}$, and the isotopic fractionation between microbial biomass and microbially derived $\mathrm{CO}_{2}$ were calculated according to Werth and Kuzyakov [11]. Bayesian isotopic mixing models (SIAR) were used to reduce uncertainties in isotopic partitioning techniques [13].

Root respiration proportion $\left(f_{\mathrm{RR}}\right)$ and the amount of root respiration $\left(Q_{R R}\right)$ are given as:

$$
\begin{gathered}
f_{R R}=1-f_{R M R}-f_{H R} \\
Q_{A R}=Q_{R R}+Q_{R M R}
\end{gathered}
$$

...where $Q_{R R}$ and $Q_{R M R}$ are the amount of root respiration and rhizomicrobial respiration, respectively.

\section{Model}

Using the findings in this study, a root-microbial model for soil respiration changing with temperature and moisture in the plantation of northern China was built by partitioning soil respiration into three components. In the root-microbial model, total soil respiration $\left(Q_{T}\right)$ could be partitioned into three parts:

$$
Q_{T}=Q_{R R}+Q_{R M R}+Q_{H R}
$$

...where $Q_{R R}, Q_{R M R}$, and $Q_{H R}$ are the amount of root respiration, rhizomicrobial respiration, and heterotrophic respiration, respectively.

Root respiration, together with rhizomicrobial respiration, was defined as microbial respiration. As the plant and soil microbial community have different temperature sensitivities, soil respiration $\left(Q_{T}\right)$ can be divided into two parts:

$$
Q_{T}=Q_{R R}+Q_{M R}
$$

...where $Q_{M R}$ is the amount of microbial respiration.

The rules of root respiration varying with soil temperature can be expressed as the inverse function of binomial function:

$$
Q_{R R}=\frac{-\mathrm{b}_{1} \pm \sqrt{\mathrm{b}_{1}{ }^{2}-4 \mathrm{a}_{1}\left(\mathrm{c}_{1}-\mathrm{T}\right)}}{2 \mathrm{a}_{1}}
$$

...where $\mathrm{T}$ is soil temperature; and $\mathrm{a}_{1}, \mathrm{~b}_{1}$, and $\mathrm{c}_{1}$ are constants. Only in the most vigorous time of root growth should " \pm " be replaced by "+". Otherwise, "." should be chosen to replace " \pm ".

Microbial respiration was positively correlated with soil temperature:

$$
Q_{M R}=\mathrm{a}_{2} \mathrm{~T}+\mathrm{b}_{2}
$$

...where $\mathrm{a}_{2}$ and $\mathrm{b}_{2}$ are constants.

Microbial respiration was mainly affected by soil moisture. Rhizomicrobial and heterotrophic respiration responded to soil moisture differently:

$$
\begin{gathered}
Q_{H R}=\mathrm{a}_{3} \mathrm{M}+\mathrm{b}_{3} \\
Q_{R M R}=\mathrm{a}_{4} \mathrm{e}^{\mathrm{b}_{4} \mathrm{M}}
\end{gathered}
$$

...where $\mathrm{M}$ is soil moisture; and $\mathrm{a}_{3}, \mathrm{a}_{4}, \mathrm{~b}_{3}$, and $\mathrm{b}_{4}$ are constants. However, Eqns. (11) and (12) were used under the condition that soil temperature was suitable for the soil microbial community.

\section{Statistics}

The values presented in the figures are given as means \pm standard errors of means $( \pm \mathrm{SEM})$. Standard errors of $f_{\mathrm{RDR}} f_{\mathrm{SDR}}$, and $f_{\text {rh }}$ were calculated as described by Phillips and Gregg [30]. Standard error of $f_{\text {RMR }}$ was calculated according to Werth and Kuzyakov [11]. The R package for SIAR was used as the method described by Parnell et al. [13]. Statistical analyses were performed with IBM SPSS statistics 21.0 (IBM Inc., New York, USA). 


\section{Results}

\section{Seasonal Variation of Soil Respiration and Soil $\mathrm{CO}_{2} \delta^{13} \mathrm{C}$}

The seasonal variation of soil respiration is shown in Fig. 1. In April, in spite of high soil moisture, soil respiration was low because of low soil temperature. Soil temperature increased but soil moisture dropped significantly in May. Soil respiration increased in May due to an increase in soil temperature. Soil moisture was low to a minimal value in June, leading to a sharp reduction in soil respiration. In July and August, soil respiration was high owing to high soil temperature and moisture. Soil respiration decreased in September, resulting from decreasing soil temperature and soil moisture. The seasonal variation of soil $\mathrm{CO}_{2} \delta^{13} \mathrm{C}$ (absolute value) showed double peaks and the peaks appeared in June and August (Fig. 1c). The $\delta^{13} \mathrm{C}$ value ranged from $-21.6 \%$ to $-24.7 \%$ for soil $\mathrm{CO}_{2}$, from $-20.6 \%$ to $-20.7 \%$ o for soil organic matter, and from $-26.0 \%$ to $-30.6 \%$ for root respiration.

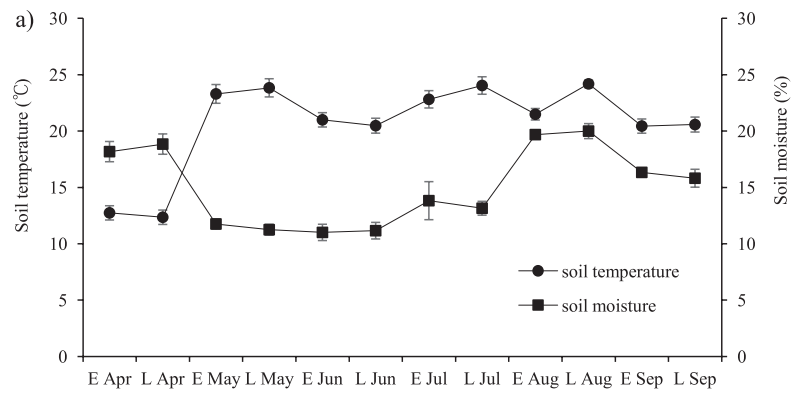

Month
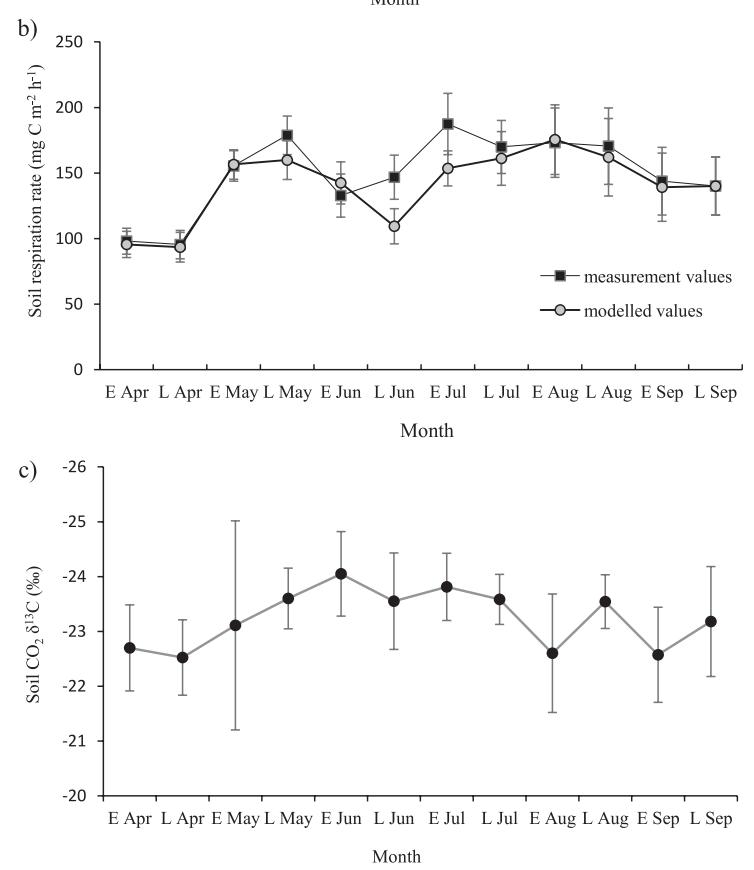

Fig. 1. Seasonal variation of soil temperature and soil moisture a), total soil respiration and modelled soil respiration b), and soil $\mathrm{CO}_{2} \delta^{13} \mathrm{C} c$ ) across sampling date $(\mathrm{n}=9)$; $\mathrm{E}$ and $\mathrm{L}$ stand for early and late.

\section{Responses of Soil Respiration to Soil Temperature and Moisture}

Soil respiration was significantly correlated with soil temperature $\left(R^{2}=0.684, P<0.01\right.$; Fig. 2a). However, the relationship between soil respiration and soil moisture was not remarkable (Fig. 2b). Soil moisture increased by $10 \%$ but was not lower than the tolerance limit of Robinia pseudoacacia. Therefore, soil moisture was not the limiting factor controlling soil respiration. The seasonal variation of soil respiration was mainly explained by soil temperature.

A significant relationship between soil respiration components and temperature sensitivity was found after autotrophic respiration was partitioned into root respiration and rhizomicrobial respiration. Root respiration significantly increased with soil temperature (Fig. 3). The values obtained in later June and earlier July were larger than those in other months (Fig. 1b). Microbial respiration was also positively correlated with soil temperature (Fig. 3), suggesting that the responses of roots and soil microorganisms to soil temperature were different.

Root respiration had no significant linear relationship with soil moisture. The components of soil respiration driven by soil microorganisms varied with soil moisture. Except for the data obtained in April (the beginning of the growing season), heterotrophic respiration was significantly positively correlated with soil moisture (Fig. 4a). However, rhizomicrobial respiration decreased significantly with soil moisture (Fig. 4b). This indicated
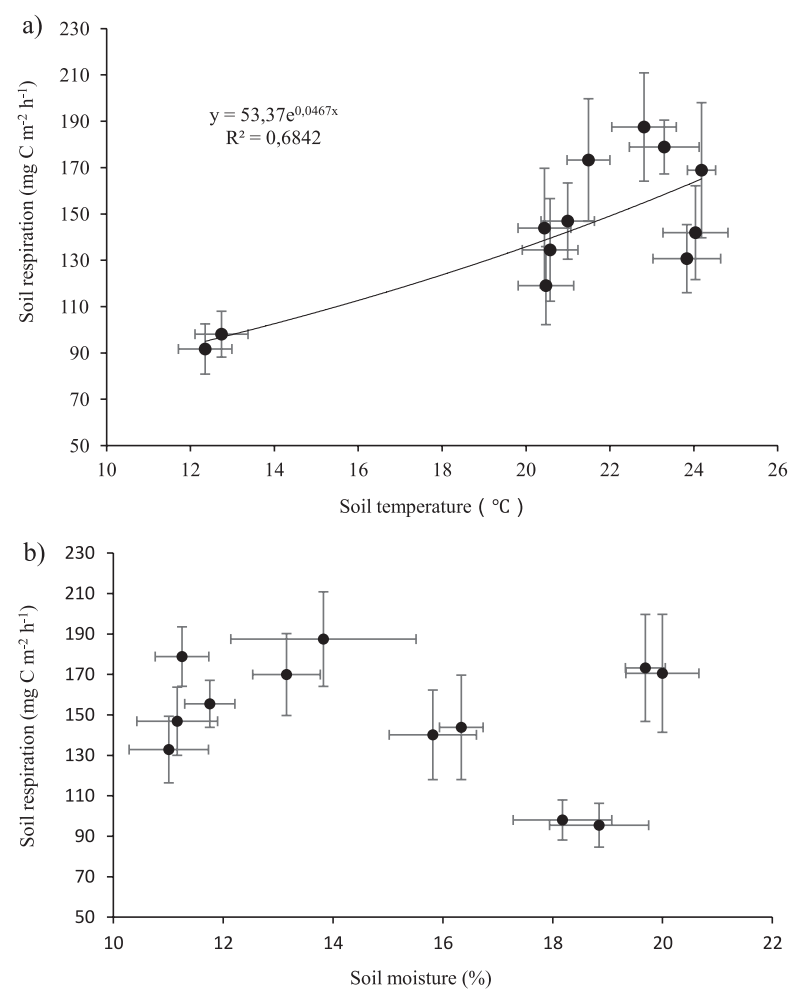

Fig. 2. Relationship between total soil respiration and soil temperature a), and soil moisture $b)(n=9)$. 


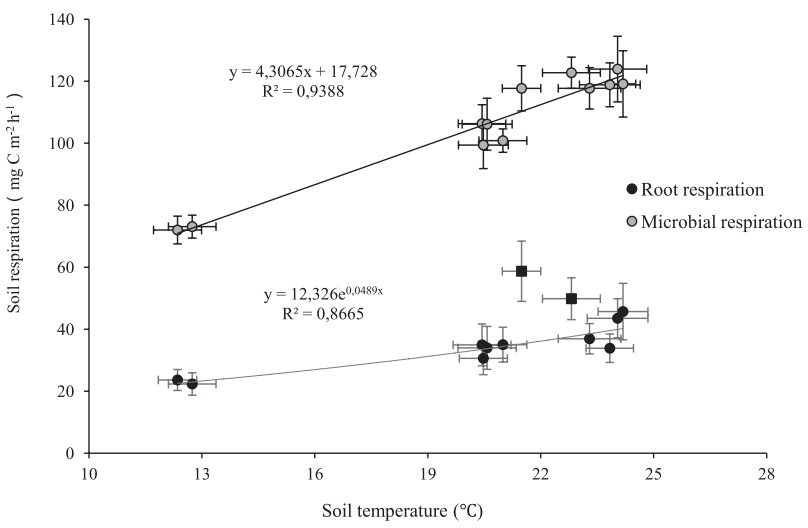

Fig. 3. Response of root and microbial respiration to soil temperature $(n=9)$.

that the source of microbial respiration (heterotrophic versus rhizomicrobial) had different moisture sensitivity in the plantation.

\section{Simulation of Root-Microbial Model}

Using the root-microbial model, measured soil respiration was well simulated (Fig. 1b). However, the root respiration measured in later June and early July was
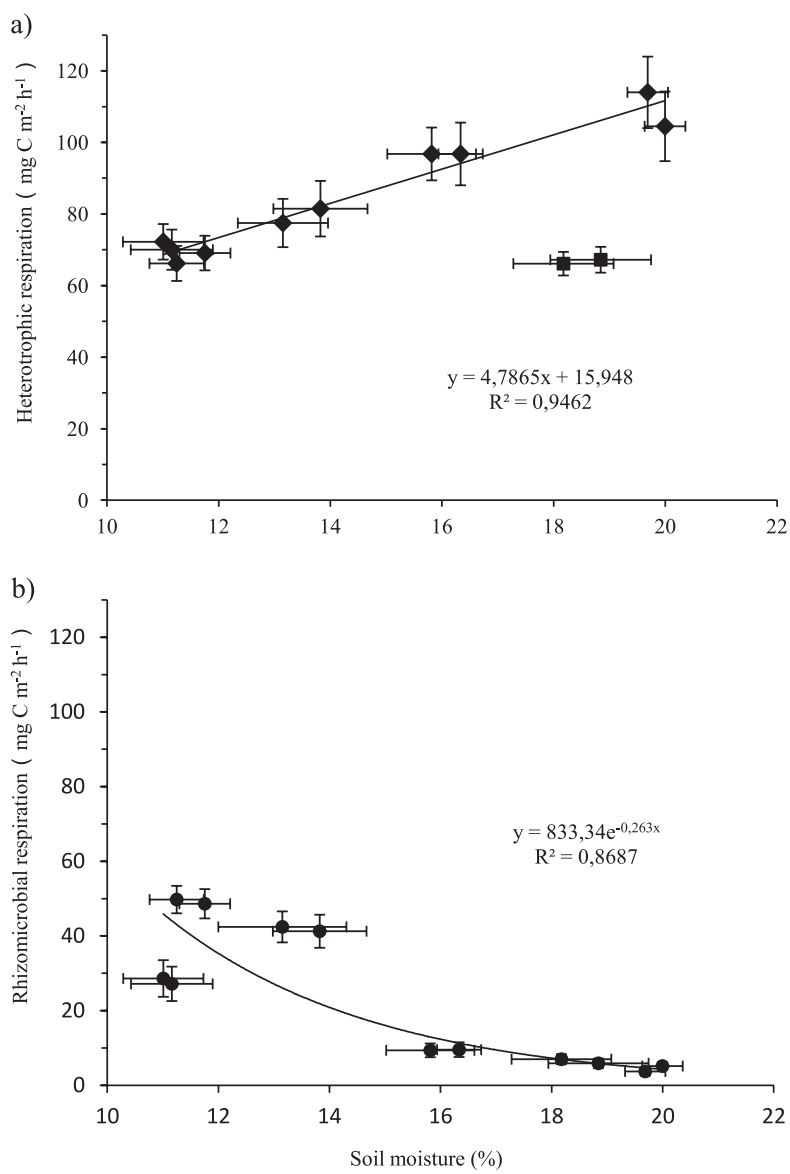

Fig. 4. Response of heterotrophic a) and rhizomicrobial b) respiration to soil moisture $(\mathrm{n}=9)$ higher than the simulated one (Fig. 1b). The root-microbial model predicted that if average soil temperature increased $2^{\circ} \mathrm{C}$ (from 20.6 to $22.6^{\circ} \mathrm{C}$ ), total soil respiration would increase $12 \mathrm{mg} \mathrm{C} \mathrm{m}^{-2} \mathrm{~h}^{-1}$ in the plantation. This means that more $\mathrm{CO}_{2}$ would be released into the atmosphere in the warm-temperate plantation. However, heterotrophic respiration will not increase if soil moisture does not rise significantly.

\section{Discussion}

\section{Temperature Sensitivity of Soil Respiration}

Under the conditions of adequate nutrition and water supply, both plant metabolism and microbial activity increase with an increase in temperature [3132]. Microbial activity was enhanced and microbial respiration increased with increasing soil temperature (Fig. 3). However, root respiration measured in later June and early July was higher than the simulated one (Fig. 1b). Steinaker and Wilson [33] pointed out that air temperature rises more rapidly than soil temperature during spring, delaying root growth into late spring or summer, while thermal buffering allows soils to remain warm through autumn. This observation was strongly supported by data obtained in the boreal zone [34]. Furthermore, belowground phenology must be in part regulated by aboveground phenology [35]. It has been shown that root growth depended on the stores of carbohydrates in plants that could fuel production as well as newly fixed carbon from aboveground organs [35-36]. High autotrophic respiration appeared in June-July, resulting in a low $\delta^{13} \mathrm{C}$, closer to the $\delta^{13} \mathrm{C}$ value of the roots (Fig. 1c). Accordingly, high root respiration obtained in late June and early July was a corollary to this observation for root growth.

The influence of temperature and resource input on soil respiration depend on the organism's mode of consumption, nutrient demands, and relative requirements for homeostasis [8]. Root respiration, rhizomicrobial respiration, and heterotrophic respiration are 3 different biological processes and their responses to environmental factors are also different [10]. Plant roots have a competition and symbiosis relationship with soil microorganisms [37]. The plant-root system is a part of the individual plant, while the associated microorganisms can be regarded as a community. Different biological bodies such as these are bound to have different response mechanisms to soil temperature. The response of root respiration to soil temperature was also affected by the aboveground part of the trees, and consistent with the overall response of the whole plant. The soil microbial community was mainly influenced by soil environment, such that microbial respiration responded in a positive way to the increase in soil temperature. The soil microbial community is comprised of a variety of microorganisms and there is no obvious boundary between microorganisms living with root exudates and SOM [37-38]. Therefore, unless a special circumstance occurred (such as extreme high or 
low temperatures), both rhizomicrobial respiration and heterotrophic respiration did not significantly vary with soil temperature.

\section{Effect of Soil Moisture on Soil Respiration}

Extreme values of soil moisture were not tested in this study but were kept within the limits of plant tolerance. The plant could adjust to changes in soil moisture, and thus root respiration did not vary significantly with soil moisture. Heterotrophic respiration was significantly positively correlated with soil moisture in the growing season (May-September) $\left(R^{2}=0.946, P<0.001\right.$; Fig. 4a). This result is similar to those found in previous studies in temperate forests of northern China [10, 39]. However, the variability in seasonal weather had a greater influence on soil respiration than soil moisture [40]. Therefore, the theoretical value of heterotrophic respiration was remarkably higher than that measured in April (Fig. 4a). In other words, at the beginning of the growing season, soil temperature was low and limiting the activity of soil microorganisms and hence led to low heterotrophic respiration.

Strong short-term changes in the turnover of SOM caused by moderate treatments of the soil are defined as the "priming effect," and the rhizosphere is the most important place where the priming effect takes place [41]. Some studies suggest that the priming effect can increase the sensitivity of SOM decomposition to soil temperature [20-21]. However, other studies have found that the increase of temperature reduced the rhizosphere priming effect [42]. The priming effect is determined by the availability of soil nutrients [43-44]. In general, high soil moisture produces a strong rhizosphere priming effect [45]. Nevertheless, rhizomicrobial respiration decreased significantly with soil moisture in the plantation (Fig. 4b). High soil moisture means there is an abundance of decomposed SOM (Fig. 4a), and soil microbes reduce the degree of activity in the rhizosphere [12, 46-47]. The reduced microbial activity in the rhizosphere can promote the reduction of plant carbon sequestration [48]. Therefore, the autotrophic components of rhizosphere priming effect become weak and rhizomicrobial respiration decreased $[46,49]$.

Microbial respiration was primarily influenced by soil moisture but root respiration had no significant relationship to soil moisture (Fig. 4). The root system has a strong ability to adjust soil moisture variation. Both rhizomicrobial respiration and heterotrophic respiration were significantly affected by soil moisture but responded differently. Heterotrophic respiration increased with the increase of soil moisture, whereas rhizomicrobial respiration decreased with increasing soil moisture (Fig. 4). This is because the nutrition sources of rhizosphere microorganisms and soil microbes differ, and the different water demands of the two processes results in a dissimilar response [49]. Because the variation of heterotrophic components caused by rhizosphere priming effect were much less than autotrophic components, the heterotrophic components were mainly driven by soil microorganisms [46]. The variation of soil water is likely to result in soil microbes varying with the rhizosphere microorganisms (or the contrary), because there is no obvious boundary between rhizosphere microorganisms and soil microorganisms [37-38]. Mutual transformation between rhizosphere microorganisms and soil microorganisms played an important role on the moisture sensitivity of soil respiration [50-51].

\section{Conclusions}

The effect of the root-microbial system on the belowground carbon balance could be reflected by the variation between environmental factors (soil temperature and moisture) and 3 components of soil respiration (heterotrophic respiration, root respiration, and rhizomicrobial respiration). The response of soil respiration to soil temperature and moisture could be seen as a function of the individual plant and the microbial community. The root system is a part of the plant controlled by physiological factors, while the soil microbial community can be divided into two parts according to different carbon sources. The two parts of the soil microbial community can mutually transform and have different responses to environmental factors. The root system and soil microbes influenced each other through symbiosis and competition. Soil respiration in forest stands could be simulated according to the rules of the variation of heterotrophic respiration, root respiration, and rhizomicrobial respiration with soil temperature and moisture. Through soil respiration, the root-microbial system plays a vital role in global carbon balance.

\section{Acknowledgements}

This study was sponsored by the National Natural Science Foundation of China (31570617, 31100322). We would also like to thank Dr. Joanne Di Maio for his assistance with English language and grammatical editing of the manuscript.

\section{References}

1. RYAN M.G., LAW B.E. Interpreting, measuring, and modeling soil respiration. Biogeochemistry 73, 3, 2005.

2. LE QUÉRÉ C., RAUPACH M.R., CANADELL J.G., MARLAND G. BOPP L., CIAIS P. Trends in the sources and sinks of carbon dioxide. Nature Geosci. 2, 831, 2009,

3. BOND-LAMBERTY B., THOMSON A. Temperatureassociated increases in the global soil respiration record. Nature 464, 579, 2010.

4. PAN Y.D., BIRDSEY R.A., FANG J.Y., HOUGHTON R., KAUPPI P.E., KURZ W.A., PHILLIPS O.L., SHVIDENKO A., LEWIS S.L., CANADELL J.G. A large and persistent carbon sink in the world's forests. Science 333, 988, 2011. 
5. GUO Z.D., HU H.F., LI P., LI N.Y., FANG J.Y. Spatiotemporal changes in biomass carbon sinks in China's forests from 1977 to 2008. Sci. China Life Sci. 56, 661, 2013.

6. PENG S.S., PIAO S.L., WANG T., SUN J.Y., SHEN Z.H. Temperature sensitivity of soil respiration in different ecosystems in China. Soil Biol. Biochem. 41, 1008, 2009.

7. HUANG Y., SUN W.J., ZHANG W., YU Y.Q. Changes in soil organic carbon of terrestrial ecosystems in China: a mini-review. Sci. China Life Sci. 53, 766, 2010.

8. CROSS W.F., HOOD J.M., BENSTEAD J.P., HURYN A.D., NELSON D. Interactions between temperature and nutrients across levels of ecological organization. Global Change Biol. 21, 1025, 2015.

9. KUZYAKOV Y. Sources of $\mathrm{CO}_{2}$ efflux from soil and review of partitioning methods. Soil Biol. Biochem. 38, 425, 2006.

10. KUZYAKOV Y. Response to the comments by Peter Högberg, Nina Buchmann and David J. Read on the review "Sources of $\mathrm{CO}_{2}$ efflux from soil and review of partitioning methods". Soil Biol. Biochem. 38, 2999, 2006.

11. WERTH, M., KUZYAKOV, Y. Three-source partitioning of $\mathrm{CO}_{2}$ efflux from maize field soil by ${ }^{13} \mathrm{C}$ natural abundance. J. Plant Nutr. Soil Sci. 172, 487, 2009.

12. SONG W.C., TONG X.J., ZHANG J.S., MENG P. Threesource partitioning of soil respiration by ${ }^{13} \mathrm{C}$ natural abundance and its variation with soil depth in a plantation. J. For. Res. 27, 533, 2016.

13. PARNELL A.C., INGER R., BEARHOP S., JACKSON A.L. Source partitioning using stable isotopes: coping with too much variation. PLoS ONE 5, e9672, 2010.

14. FANG C., SMITH P., MONCRIEFF J.B., SMITH J.U. Similar response of labile and resistant soil organic matter pools to changes in temperature. Nature 433, 57, 2005.

15. DAVIDSON E.A., JANSSENS I.A. Temperature sensitivity of soil carbon decomposition and feedbacks to climate change Nature 440, 165, 2006.

16. BALSER T.C., WIXON D.L. Investigating biological control over soil carbon temperature sensitivity. Global Change Biol. 15, 2935, 2009.

17. MALCOLM G.M., LO'PEZ-GUTIE'RREZ J.C., KOIDE R.T. Temperature sensitivity of respiration differs among forest floor layers in a Pinus resinosa plantation. Soil Biol. Biochem. 41, 1075, 2009.

18. JANSSENS I.A., PILEGAARD K. Large seasonal changes in $\mathrm{Q}_{10}$ of soil respiration in a beech forest. Global Change Biol. 9, 911, 2003.

19. ZHENG Z.M., YU G.R., FU Y.L., WANG Y.S., SUN X.M., WANG Y.H. Temperature sensitivity of soil respiration is affected by prevailing climatic conditions and soil organic carbon content: A trans-China based case study. Soil Biol. Biochem. 41, 1531, 2009.

20. ZHU B., CHENG W.X. Rhizosphere priming effect increases the temperature sensitivity of soil organic matter decomposition. Global Change Biol. 17, 2172, 2011.

21. THIESSEN S., GLEIXNER G., WUTZLER T., REICHSTEIN M. Both priming and temperature sensitivity of soil organic matter decomposition depended on microbial biomass - an incubation study. Soil Biol. Biochem. 57, 739, 2013.

22. KOCH O, TSCHERKO D, KANDELER E. Temperature sensitivity of microbial respiration - nitrogen mineralization - and potential soil enzyme activities in organic alpine soils. Global Biogeochem. Cy. 21, GB4017, 2007.

23. WOOD T.E., DETTO M., SILVER W.L. Sensitivity of soil respiration to variability in soil moisture and temperature in a humid tropical forest. PLoS ONE 8, e80965, 2013.
24. MOYANO F.E., MANZONI S., CHENU C. Responses of soil heterotrophic respiration to moisture availability: An exploration of processes and models. Soil Biol. Biochem. 59, 72, 2013.

25. ATARASHI-ANDOH M., KOARASHI J., ISHIZUKA S., HIRAI K. Seasonal patterns and control factors of $\mathrm{CO}_{2}$ effluxes from surface litter, soil organic carbon, and rootderived carbon estimated using radiocarbon signatures. Agr. Forest Meteorol. 152, 149, 2012.

26. PATAKI D.E., EHLERINGER J.R., FLANAGAN L.B., YAKIR D., BOWLING D.R., STILL C.J., BUCHMANN N., KAPLAN J.O., BERRY J.A. The application and interpretation of Keeling plots in terrestrial carbon cycle research. Global Biogeochem. Cy. 17, 1022, 2003.

27. WERTH M., SUBBOTINA I., KUZYAKOV Y. Threesource partitioning of $\mathrm{CO}_{2}$ efflux from soil planted with maize by ${ }^{13} \mathrm{C}$ natural abundance fails due to inactive microbial biomass. Soil Biol. Biochem. 38, 2772, 2006.

28. MILLARD P., MIDWOOD A.J., HUNT J.E., BARBOUR M.M., WHITEHEAD D. Quantifying the contribution of soil organic matter turnover to forest soil respiration, using natural abundance $\delta^{13} \mathrm{C}$. Soil Biol. Biochem. 42, 935, 2010.

29. KUZYAKOV Y. Theoretical background for partitioning of root and rhizomicrobial respiration by ${ }^{13} \mathrm{C}$ of microbial biomass. Eur. J. Soil Biol. 41, 1, 2005.

30. PHILLIPS D.L., GREGG J.W. Uncertainty in source partitioning using stable isotopes. Oecologia 127, 171, 2001.

31. DIELEMAN W.I.J., VICCA S., DIJKSTRA F.A., HAGEDORN F., HOVENDEN M.J., LARSEN K.S., MORGAN J.A., VOLDER A., BEIER C., DUKES J.S. Simple additive effects are rare: a quantitative review of plant biomass and soil process responses to combined manipulations of $\mathrm{CO}_{2}$ and temperature. Global Change Biol. 18, 2681, 2012.

32. BRADFORD M.A. Thermal adaptation of decomposer communities in warming soils. Front. Microbiol. 4, 333, 2013.

33. STEINAKER D.F., WILSON S.D. Phenology of fine roots and leaves in forest and grassland. J. Ecol. 96, 1222, 2008.

34. ROSE Z.A., ADRIEN C.F. Are above- and below-ground phenology in sync? New Phytol. 205, 1054, 2015.

35. LITTON C.M., RAICH J.W., RYAN M.G. Carbon allocation in forest ecosystems. Global Change Biol. 13, 2089, 2007.

36. TEFS C., GLEIXNER G. Importance of root derived carbon for soil organic matter storage in a temperate oldgrowth beech forest - Evidence from $\mathrm{C}, \mathrm{N}$ and ${ }^{14} \mathrm{C}$ content. Forest Ecol. Manag. 263, 131, 2012.

37. KUZYAKOV Y., XU X. Competition between roots and microorganisms for nitrogen: mechanisms and ecological relevance. New Phytol. 198, 656, 2013.

38. BLAGODATSKAYA E.V., KUZYAKOV Y. Active microorganisms in soil: critical review of estimation criteria and approaches. Soil Biol. Biochem. 67, 192, 2013.

39. LI P., YANG Y., FANG J. Variations of root and heterotrophic respiration along environmental gradients in China's forests. J. Plant Ecol. 6, 358, 2013.

40. NIELSEN U.N., BALL B.A. Impacts of altered precipitation regimes on soil communities and biogeochemistry in arid and semi-arid ecosystems. Global Change Biol. 21, 1407, 2015.

41. KUZYAKOV, Y. Priming effects: interactions between living and dead organic matter. Soil Biol. Biochem. 42, 1363, 2010. 
42. KUZYAKOV Y., HILL P.W., JONES D.L. Root exudate components change litter decomposition in a simulated rhizosphere depending on temperature. Plant Soil 290, 293, 2007.

43. DIJKSTRA F.A., CARRILLO Y., PENDALL E., PENDALL E., MORGAN J.A. Rhizosphere priming: a nutrient perspective. Front Microbiol. 39, 600, 2013.

44. SULLIVAN B.W., HART S.C. Evaluation of mechanisms controlling the priming of soil carbon along a substrate age gradient. Soil Biol. Biochem. 58, 293, 2013.

45. DIJKSTRA F.A., CHENG W.X. Moisture modulates rhizosphere effects on $\mathrm{C}$ decomposition in two different soil types. Soil Biol. Biochem. 39, 2264, 2007.

46. SONG W.C., TONG X.J., ZHANG J.S., MENG P., LI J. Autotrophic and heterotrophic components of soil respiration caused by rhizosphere priming effects in a plantation. Plant Soil Environ. 63, 295, 2017.

47. GEISSELER D., HORWATH W.R., SCOW K.M. Soil moisture and plant residue addition interact in their effect on extracellular enzyme activity. Pedobiologia 54, 71, 2011.
48. SONG W.C., LIU Y.H., TONG X.J. Newly sequestrated soil organic carbon varies with soil depth and tree species in three forest plantations from northeastern China. Forest Ecol. Manag. 400, 384, 2017.

49. BLAGODATSKAYA E.V., KUZYAKOV Y. Mechanisms of real and apparent priming effects and their dependence on soil microbial biomass and community structure: critical review. Biol. Fert. Soils 45, 115, 2008.

50. CHENG, W.X. Rhizosphere priming effect: its functional relationships with microbial turnover, evapotranspiration, and C-N budgets. Soil Biol. Biochem. 41, 1795, 2009.

51. BURNS R.G., DEFOREST J.L., MARXSEN J., SINSABAUGH R.L., STROMBERGER M.E., WALLENSTEIN M.D., WEINTRAUB M.N., ZOPPINI A. Soil enzymes in a changing environment: current knowledge and future directions. Soil Biol. Biochem. 58, $216,2013$. 